\title{
Pengaruh Kualitas Sistem, Kualitas Informasi, dan Kualitas Layanan Terhadap Kepuasan Konsumen (Studi Pada Pengguna Aplikasi Berrybenka di Kota Bandung)
}

\author{
Shanaz Amarin ${ }^{1}$; Tri Indra Wijaksana ${ }^{2}$ \\ Administrasi Bisnis, Universitas Telkom, Bandung ${ }^{1,2}$ \\ Email korespondensi: $\underline{\text { shanazamarin@gmail.com }}{ }^{1}$, triindrawijaksana@telkomuniversity.ac.id ${ }^{2}$ \\ Received: 6 Mar 2021 Reviewed: 12 Mar 2021 Accepted: 19 Mar 2021 Published: 30 Apr 2021
}

\begin{abstract}
This study aims to determine the relation between the variables of system quality, information quality, and service quality on customer satisfaction based on consumer experience using the Berrybenka application in Bandung. The data analysis used was quantitative as well as descriptive and causal methods. Likert scale was chosen to test the questionnaire of this study. Consumers who use the Berrybenka application who lives in Bandung are the population in this research. There are 150 samples used that have been obtained from distributing questionnaires to respondents. Non-probability sampling and purposive sampling techniques were used to determine the characteristics of the population tested in this study. After conducting the research, it is found that there is no partial relationship between system quality and customer satisfaction, while information quality and service quality have relationships with customer satisfaction. Furthermore, simultaneously, system quality, information quality, and service quality have relationship with customer satisfaction.
\end{abstract}

Keywords: system quality, information quality, service quality, customer satisfaction

\begin{abstract}
ABSTRAK
Penelitian ini dilakukan untuk menentukan hubungan antara variabel kualitas sistem, kualitas informasi, dan kualitas layanan terhadap kepuasan konsumen berdasarkan pengalaman konsumen menggunakan aplikasi Berrybenka di Kota Bandung. Menggunakan analisis metode kuantitatif serta deskriptif dan kausal serta skala Likert dipilih untuk menguji kuesioner penelitian ini. Konsumen yang menggunakan aplikasi Berrybenka yang berdomisili di Kota Bandung adalah populasi dalam penelitian ini. Terdapat 150 sampel yang digunakan dan diperoleh dari penyebaran kuesioner ke responden. Teknik non-probability sampling, dan purposive sampling digunakan untuk menentukan karakteristik dari populasi yang diuji di penelitian ini. Setelah dilakukannya penelitian, didapat hasil bahwa secara parsial tidak ada hubungan antara kualitas sistem dengan kepuasan konsumen, sementara itu untuk kualitas informasi dan kualitas layanan ada kaitannya dengan kepuasan konsumen. Selanjutnya secara simultan, kualitas sistem, kualitas informasi, dan kualitas layanan ada memiliki kaitan dengan kepuasan konsumen.
\end{abstract}

Kata kunci: kualitas sistem, kualitas informasi, kualitas layanan, kepuasan konsumen

\section{A. PENDAhULUAN}

Era globalisasi, pertumbuhan ekonomi serta perkembangan teknologi di Indonesia berkembang dengan sangat pesat, hal itu dapat dilihat dengan pengguna internet yang semakin 
banyak. Internet dapat memberikan kemudahan bagi penggunanya sehingga membuat penggunanya dapat menggunakan internet dengan sangat mudah. Pesatnya pertumbuhan internet di Indonesia juga dimuat dalam artikel berita. Pratomo (2019) menyatakan bahwa menurut hasil survei pada tahun 2018 pengguna internet di Indonesia mengalami kenaikan. Menurut hasil survei, pada tahun 2018 adanya kenaikan hingga 171,17 juta pengguna untuk pengguna internet.

Meningkatnya pengguna internet juga turut meningkatkan kegiatan e-commerce. Internet sangat berperan dalam mendukung perkembangan e-commerce, terutama dalam meningkatkan transaksi jual beli. Saat ini, banyak sekali pelaku usaha yang beralih menggunakan e-commerce sebagai media untuk memasarkan produknya. Hal itu didukung dengan banyaknya e-commerce di Indonesia. Seperti yang dikutip dari situs Warta Ekonomi (2019), dari tahun ke tahun, Indonesia adalah pasar dengan perkembangan e-commerce yang menarik. Menurut data tahun 2018, terjadi pertumbuhan pesat mengenai e-commerce di Indonesia dan akan terus berkembang karena jumlah pengusaha yang menggunakan $e$ commerce semakin banyak termasuk pelaku UMKM.

Menurut Sirclo (2020), yaitu situs untuk menyediakan pelayanan dan software solusi $e$ commerce untuk lokal bisnis di Indonesia menyebutkan hasil riset yang dilakukan oleh Nielsen, sampai tahun 2020 produk pakaian masih menjadi kategori yang paling banyak dicari hingga mencapai $61 \%$ konsumen. Ketika berbelanja secara online, penggunaan aplikasi mobile adalah langkah pertama untuk melakukan belanja online. Penggunaan aplikasi mobile ini dilakukan pembeli untuk melakukan pencarian informasi tentang detail produk yang dicari, ukuran baju, hingga melakukan perbandingan harga. Dengan adanya aplikasi mobile, tentu sangat mempermudah konsumen untuk menemukan produk yang sesuai dengan keinginan. Dalam hal ini, aplikasi mobile dalam smartphone digunakan oleh perusahaan untuk memberikan layanan berbasis online. Seiring dengan pesatnya perkembangan zaman, Berrybenka menyediakan layanan melalui aplikasi mobile Android dan iOS. Dengan diluncurkannya aplikasi Berrybenka, pengguna Android dan iOS dapat berbelanja dengan cepat dan mudah jika dibanding dengan mengakses website Berrybenka.com melalui peramban.

Walaupun adanya aplikasi mobile Berrybenka yang memberikan kemudahan dan kepraktisan dalam berbelanja online, ada beberapa tanggapan pengguna tentang aplikasi Berrybenka di App Store maupun Play Store. Rating Berrybenka di App Store hanya sebesar 3.0 dari 5 saja, sedangkan di Play Store aplikasi Berrybenka memiliki rating 4.2 dari 5. Berrybenka sangat memperhatikan keamanan sistem informasi website dan aplikasinya 
dengan teliti. Dengan melakukan pemeriksaan keamanan dalam menghadapi kemungkinan adanya celah keamanan sistem di segala aspek layanan.

Berdasarkan ulasan pengguna aplikasi Berrybenka di App Store maupun di Play Store, banyak sekali pengguna yang mengeluhkan aplikasi sering mengalami error, tidak bisa login, aplikasi lambat dan kurang responsif. Dengan demikian, tidak sedikit pengguna yang lebih memilih berbelanja melalui website Berrybenka daripada melalui aplikasi. Hal tersebut menunjukkan adanya masalah pada sistem aplikasi Berrybenka.

Beberapa penelitian terdahulu oleh Rudini (2015), Suhendro (2016), Pawirosumarto (2016), Marlissa (2015), Puspa (2017), Brata et al. (2018). Hasil penelitian tersebut menyatakan variabel yang diteliti saling berhubungan satu sama lain. Namun, dari penelitian tersebut objek yang diteliti bukan aplikasi e-commerce melainkan aplikasi pelayanan masyarakat. Sedangkan penelitian oleh Saraswati (2016), penelitian tersebut menggunakan objek penelitian yang sama yaitu aplikasi e-commerce dan temuannya menyatakan bahwa memiliki hubungan yang positif.

Berdasarkan uraian tersebut, belum ada penelitian yang secara spesifik menggunakan aplikasi e-commerce Berrybenka sebagai objek penelitiannya. Hal itu menjadi dasar dilakukannya penelitian yang berjudul Pengaruh Kualitas Sistem, Kualitas Informasi, dan Kualitas Layanan terhadap Kepuasan Konsumen (Studi pada Aplikasi Berrybenka). Adapun penelitian ini bertujuan untuk mencari tahu hubungan variabel kualitas sistem, kualitas informasi, dan kualitas layanan terhadap variabel kepuasan konsumen pada pengguna aplikasi Berrybenka di Kota Bandung. Hasil temuan dari riset ini semoga bisa bermanfaat untuk dijadikan acuan pada penelitian selanjutnya, terutama untuk penelitian yang variabel bebas dan variabel terikatnya sama dengan penelitian ini.

\section{B. TELAAH PUSTAKA}

\section{Kualitas Sistem}

Kualitas sistem merupakan bagaimana sebuah sistem bekerja secara baik dan maksimal agar dapat menghasilkan output yang sesuai dengan harapan pengguna sistem. DeLone \& McLean (2003), mendefinisikan kualitas sistem adalah tanda atau yang berkaitan tentang kualitas yang diharapkan sebuah sistem tersebut dan kualitas penginformasian yang tepat mengenai ciri suatu produk. Dalam sebuah sistem informasi, kualitas sistem adalah gabungan perangkat lunak dan perangkat keras yang bekerja di dalam sistem. Kualitas sistem bisa dijadikan ukuran karakteristik pada saat mengakses aplikasi Berrybenka seperti penggunaan yang mudah, sistem yang dapat diandalkan, akses cepat, sistem yang fleksibel, dan keamanan. 


\section{Kualitas Informasi}

Kualitas informasi adalah bagaimana sebuah informasi disajikan secara lengkap dan jelas serta dapat mengedukasi pengguna. Ketika ingin membeli sebuah produk. Kelengkapan informasi menjadi poin utama untuk dijadikan dasar bagi konsumen ketika akan melakukan pengambilan keputusan dalam membeli produk. Seddon (1997), mendefinisikan manfaat yang didapatkan akan berpengaruh untuk persepsi konsumen pengguna layanan informasi. Kualitas informasi merupakan tolak ukur untuk konsumen dalam pemenuhan syarat dan ekspektasi orang-orang yang memerlukan informasi untuk melakukan pengambilan keputusan.

DeLone \& McLean (2003), berpendapat kualitas informasi merupakan ketika produk adanya detail informasi yang jelas sehingga memiliki nilai. Kualitas informasi dinilai berdasarkan isi, ketepatan, relevan, dan kegunaan yang dihasilkan dari informasi tersebut. Sedangkan menurut Seddon (1997), menyatakan kualitas informasi berpengaruh dalam proses pengambilan keputusan. Kualitas informasi adalah ketika informasi dapat dengan mudah dicerna oleh pengguna sistem sehingga memiliki manfaat. Adapun indikator pengukuran kualitas informasi menurut Jogiyanto (2009), yaitu: (1) akurat; (2) relevan; (3) kelengkapan; (4) mudah dimengerti.

\section{Kualitas Layanan}

DeLone \& McLean (2003), mendefinisikan kualitas layanan adalah layanan yang difasilitasi dari pengembang untuk pengguna. Pelayanan yang didapat misalnya adalah pembaharuan aplikasi, dan ulasan dari pengembang terkait jika ada masalah di dalam aplikasi tersebut. Kualitas layanan yaitu keseluruhan pendukung yang disampaikan oleh pengembang sistem kepada pengguna dengan pemberian jaminan keamanan, kenyamanan, empati, dan ketanggapan dalam memenuhi harapan konsumen. Jika kualitas layanan yang diberikan maksimal, otomatis kepuasan konsumen akan mengalami peningkatan. Jika konsumen senang dengan pelayanan yang difasilitasi, maka konsumen selalu menggunakannya secara berkelanjutan. Kualitas layanan memiliki tiga indikator, yaitu responsif, penjaminan, dan rasa empati (DeLone \& McLean, 2003).

\section{Kepuasan Konsumen}

Kata puas (satisfaction) memiliki asal dari bahasa latin "satis" (baik, sesuai) dan "facio" (melakukan atau membuat). Kepuasan dapat memiliki arti "memiliki perasaan yang baik ketika kita berhasil meraih sesuatu yang kita inginkan", "suatu cara untuk pemenuhan kebutuhan”, dan "perbuatan yang dilakukan untuk menyelesaikan masalah". Hornby, (2015).

Kotler \& Keller (2009), mendefinisikan kepuasan konsumen adalah sesuatu yang melibatkan rasa senang dan rasa kecewa karena membandingkan kinerja yang diharapkan 
dengan kenyataan. Jika hasilnya sesuai apa yang diharapkan, konsumen akan merasa puas. Kepuasan konsumen adalah jika apa yang diharapkan oleh konsumen sesuai dengan ekspektasi awal ketika sebelum menggunakan produk (Lupioadi \& Hamdani, 2006).

\section{Kerangka Teoritis}

\section{Hubungan Kualitas Sistem terhadap Kepuasan Konsumen}

Kualitas sistem dapat berhubungan dengan proses untuk mengolah sistem informasi tersebut. Jika ketika sedang menggunakan sistem pengguna merasa adanya sistem yang stabil dan dapat meringankan untuk pekerjaan dan menjadikan pekerjaan mereka lebih cepat dan menghemat waktu, dapat disimpulkan pengguna tersebut puas dengan sistem informasi yang diberikan. Tingginya tingkat kestabilan yang dihasilkan, maka pemakai pun akan puas dengan hasilnya (DeLone \& McLean, 2003).

Kepuasan konsumen adalah tanggapan atas apa yang dirasakan oleh konsumen ketika sesudah memakai sistem informasi. Hal itu dapat dijadikan acuan untuk pengukuran tingkat kepuasan konsumen melalui tingkat kepuasan tentang hasil atau output yang keluar, serta adanya pendukung oleh pengembang sistem. (DeLone \& McLean, 2003).

\section{Hubungan Kualitas Informasi terhadap Kepuasan Konsumen}

Kualitas informasi adalah ciri dari hasil yang diperoleh di sistem informasi yang diantaranya adalah manajemen dan web (DeLone \& McLean, 2003). Berdasarkan hal tersebut, dapat diukur untuk melihat seberapa layak luaran yang diperoleh dari sistem informasi yang digunakan. Kualitas informasi adalah sebuah hasil yang dapat berupa kumpulan informasi untuk selanjutnya digunakan dan dijadikan acuan (Puspa, 2017). Jika kualitas yang dihasilkan baik, secara otomatis dapat diandalkan untuk membuat keputusan. Jika informasi yang dihasilkan kurang baik, akan berdampak pada kepuasan yang menggunakan sistem tersebut.

Mengutip dari Kotler, (2005) perasaan puas adalah ekspresi yang dibuat oleh seseorang ketika hasil dari ekspektasi dan kenyataan dalam sebuah produk atau kinerja yang sesuai dengan harapan ketika sebelum menggunakan produk atau kinerja tersebut. Sebagai pengguna sistem sudah pasti akan menaruh harapan besar dalam menggunakan sistem, pengguna akan berharap sistem dapat berjalan sesuai dengan ekspektasi pengguna. Ciri yang dihasilkan dari informasi yang diperoleh dapat terjadi perbedaan dengan sistem lainnya. Sistem informasi yang berkualitas yaitu dapat tepat waktu, tingkat akurasi yang tinggi, tepat guna, dan dapat memenuhi ekspektasi dari penggunanya. Hal tersebut tentu akan memiliki pengaruh besar dalam kepuasan yang memakai sistem tersebut.

Kepuasan pengguna dapat terbentuk jika suatu informasi yang disampaikan dapat diperbaharui, terjadi secara konsisten, akurasi yang tinggi, serta tepat. Jika kepuasan pemakai 
sistem informasi dapat meningkat, maka seterusnya kepuasan pengguna akan mengalami peningkatan pula. (Puspa, 2017).

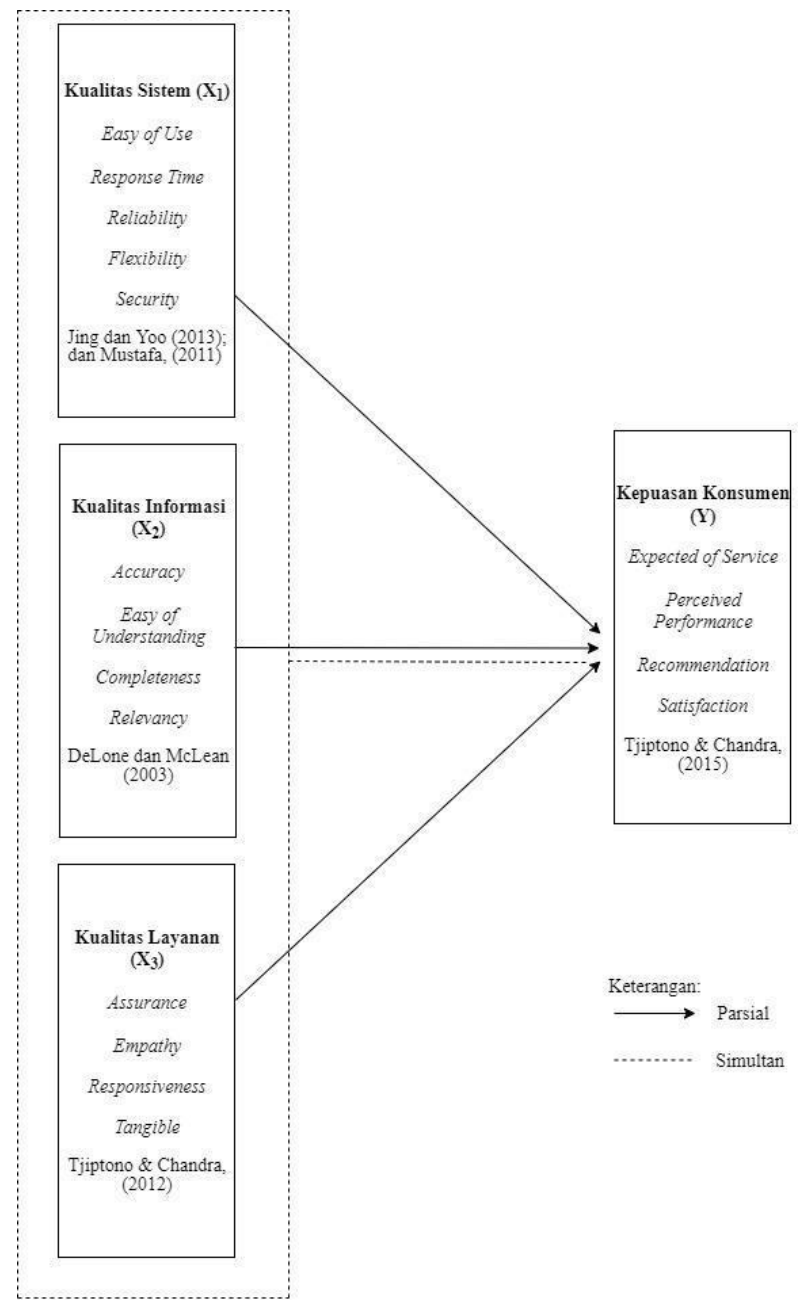

Gambar 1. Kerangka Teoritis

\section{Hubungan Kualitas Layanan terhadap Kepuasan Konsumen}

Produk dari kualitas layanan bisa berbentuk pembaharuan sistem dan feedback dari pengembang apabila sistem informasi menghadapi permasalahan. Kualitas layanan yang baik akan membuat konsumen senang dan merasa terbantu dengan pelayanan yang diberikan. Kualitas layanan adalah solusi untuk memenuhi keperluan dan kemauan pelanggan dan keakuratan dalam penyampaiannya agar menyeimbangkan ekspektasi dari pelanggan. (Tjiptono, 2006).

\section{Hipotesis Penelitian}

$\mathrm{H}_{1}$ : Kualitas sistem, kualitas informasi, dan kualitas layanan berpengaruh secara simultan terhadap kepuasan konsumen pengguna aplikasi Berrybenka

$\mathrm{H}_{2}$ : Kualitas sistem berpengaruh secara parsial terhadap kepuasan konsumen aplikasi Berrybenka 
$\mathrm{H}_{3}$ : Kualitas informasi berpengaruh secara pasial terhadap kepuasan konsumen aplikasi Berrybenka

$\mathrm{H}_{4}$ : Kualitas layanan berpengaruh secara parsial terhadap kepuasan konsumen aplikasi Berrybenka

\section{METODE PENELITIAN}

Data primer menggunakan kuesioner yang diperoleh dengan menyebarkannya ke responden. Kuesioner pada penelitian ini disebarkan kepada responden yang pernah berbelanja online melalui aplikasi Berrybenka. Pada penelitian ini kuesioner disebarkan secara online melalui web Google Form. Link dari dokumen kuesioner ini disebarkan melalui instant messenger Line, dan media sosial seperti Instagram atau Twitter, khususnya di akun media sosial Berrybenka. Rentang waktu penyebaran kuesioner untuk penelitian ini dimulai pada bulan Mei 2020 hingga bulan Juni 2020.

Dalam penelitian ini menggunakan metode kuantitatif serta deskriptif dan kausal. Populasi yang dipilih adalah orang yang memiliki pengalaman memakai aplikasi Berrybenka yang ada di Kota Bandung. Penelitian ini menggunakan sampel sebesar 150 responden. Jenis pengumpulan sampel yang dipakai adalah dengan jenis non probability sampling, dan purposive sampling sebagai tekniknya. Teknik purposive sampling merupakan teknik menentukan anggota sampel yang spesifik terencana ditentukan oleh peneliti. Hal ini disebabkan untuk bisa memberitahu informasi yang relevan hanya sampel tersebut saja yang dapat mewakilinya serta untuk dapat mendapatkan informasi yang diinginkan. (Priyantara, 2016). Kriteria populasi untuk melakukan penelitian ini adalah pertama adalah mengetahui $E$ Commerce Berrybenka. Kedua, pernah melakukan pembelian di Berrybenka minimal satu kali, karena jika sudah pernah melakukan pembelian di Berrybenka responden akan familiar dan mengetahui dengan prosedur yang diterapkan oleh Berrybenka. Kriteria ketiga adalah berdomisili di Kota Bandung.

Dimensi variabel yang dipakai untuk mengumpulkan data, yakni dimensi kualitas sistem, dimensi kualitas informasi, dimensi kualitas layanan, dan dimensi kepuasan konsumen. Dimensi kualitas sistem diperoleh dari dimensi yang disampaikan oleh DeLone \& McLean (2003), yaitu kemudahan pengguna, akses cepat (fast), sistem yang andal, fleksibilitas, dan keamanan. Dimensi kualitas informasi diperoleh dari dimensi yang dijelaskan oleh DeLone \& McLean (2003), yaitu ketepatan, mudah dipahami (easy of understanding), kelengkapan (compeleteness), dan relevan (relevancy). Dimensi kualitas layanan diperoleh dari dimensi yang dikemukakan oleh Tjiptono \& Chandra (2012), yaitu jaminan, empati, daya tanggap, dan 
bukti fisik. Dimensi kepuasan konsumen diperoleh dari dimensi yang dikemukakan oleh Tjiptono \& Chandra (2015), yaitu layanan yang diharapkan (expected of service), kinerja yang dirasakan (perceived performance), rekomendasi (recommendation), dan kepuasan (satisfaction). Dari data penelitian yang diperoleh, semua dimensi tersebut dibuat pernyataan dalam bentuk kuesioner serta menggunakan Skala Likert untuk mengukur dimensi tersebut kemudian dilakukan uji koefisien determinasi, uji F tabel, dan uji t table

\section{HASIL DAN PEMBAHASAN}

\section{Karakteristik Responden berdasarkan Jenis Kelamin}

Tabel 1. Karakteristik Berdasarkan Jenis Kelamin

\begin{tabular}{lr}
\hline Jenis Kelamin & Jumlah \\
\hline Laki-laki & 50 \\
Perempuan & 100 \\
\hline TOTAL & 150 \\
\hline \multicolumn{2}{c}{ Sumber: Data Diolah, 2020 }
\end{tabular}

Responden yang memiliki jenis kelamin pria sebanyak 50 orang memiliki nilai 33,3\% dan wanita sebanyak 100 orang memiliki nilai $66,7 \%$. Sehingga jumlah total pria dan wanita adalah sebanyak 150 orang. Jadi karakteristik responden pelanggan Berrybenka yang paling dominan adalah berjenis kelamin wanita.

\section{Karakteristik Responden berdasarkan Usia}

Jumlah responden yang berusia 15-25 tahun berada di urutan pertama adalah 96 orang dengan nilai persentase 64\% kemudian responden yang memiliki usia 26-30 tahun ada di urutan kedua yaitu 40 orang memiliki nilai 26,7\% kemudian responden yang memiliki usia > 30 tahun berada di urutan ketiga yaitu 14 orang memiliki nilai 9,3\%. Dengan demikian, karakteristik responden pelanggan Berrybenka yang paling dominan adalah yang berusia 15-25 tahun.

Tabel 2. Karakteristik berdasarkan Usia

\begin{tabular}{|c|c|}
\hline Usia & Jumlah \\
\hline $15-25$ tahun & 96 \\
\hline 26-30 tahun & 40 \\
\hline$>30$ tahun & 14 \\
\hline TOTAL & 150 \\
\hline
\end{tabular}

\section{Karakteristik Responden berdasarkan Pekerjaan}

Jumlah responden yang memiliki status mahasiswa berada di urutan pertama ada 93 orang memiliki nilai $62 \%$. Selanjutnya responden pegawai berada di urutan kedua ada 33 orang memiliki nilai $22 \%$. Responden yang masih berstatus pelajar ada di urutan ketiga ada 16 orang 
memiliki nilai $10,7 \%$. Responden yang memiliki pekerjaan sebagai lainnya (ibu rumah tangga, freelancer, fotografer) di urutan keempat ada 6 orang memiliki nilai 4\%, dan responden yang memiliki pekerjaan wiraswasta ada diurutan kelima yaitu 2 orang memiliki nilai 1,3\%. Jadi karakteristik pelanggan Berrybenka yang paling dominan adalah yang memiliki pekerjaan sebagai mahasiswa.

Tabel 3. Karakteristik berdasarkan Pekerjaan

\begin{tabular}{|c|c|}
\hline Pekerjaan & Jumlah \\
\hline Pegawai & 33 \\
\hline Mahasiswa & 93 \\
\hline Pelajar & 16 \\
\hline Wiraswasta & 2 \\
\hline Lainnya (Ibu Rumah Tangga, Freelancer, Fotografer) & 6 \\
\hline TOTAL & 150 \\
\hline
\end{tabular}

Sumber: Data diolah, 2020

\section{Karakteristik Responden berdasarkan Pengeluaran Per Bulan untuk Berbelanja Online}

Jumlah responden berpengeluaran Rp. 500.000 - Rp. 1.000 .000 berada di urutan kepertama, ada 84 orang memiliki nilai 56\%. Kemudian responden dengan pengeluaran Rp 1.000.000 - 3.000.000 berada di urutan ke-2, ada 36 orang memiliki nilai $24 \%$. Sementara itu responden dengan pengeluaran $<\mathrm{Rp} 500.000$ berada di urutan ke-3, ada 16 orang memiliki nilai 10,7\%. Dan responden dengan pengeluaran $>$ Rp 3.000.000 berada di urutan ke-4, ada 14 orang memiliki nilai 9,3\%. Jadi, karakteristik responden pelanggan Berrybenka yang paling dominan adalah yang berpengeluaran antara Rp 500.000 - Rp 1.000.000. Hal tersebut sesuai dengan target market Berrybenka yaitu untuk kalangan menengah dengan menawarkan harga yang terjangkau (Berrybenka, 2020).

Tabel 4. Karakteristik berdasarkan Pengeluaran Per Bulan untuk Berbelanja Online

\begin{tabular}{lr}
\hline Pengeluaran Perbulan & Jumlah \\
\hline$<\operatorname{Rp} 500.000$ & 16 \\
Rp 500.000-1.000.000 & 84 \\
Rp 1.000.000-3.000.000 & 36 \\
$>$ Rp 3.000.000 & 14 \\
\hline TOTAL & 150 \\
\hline
\end{tabular}

Sumber: Data diolah, 2020

\section{Karakteristik Responden yang Mengetahui Berrybenka}

Jumlah responden yang mengetahui e-commerce Berrybenka dari sosial media berada di urutan pertama yaitu sebanyak 124 orang dengan persentase sebesar $82,7 \%$. Hal tersebut sesuai dengan gencarnya promosi oleh Berrybenka melalui sosial lewat seperti instagram, twitter, dan sebagainya. Kemudian responden yang mengetahui Berrybenka dari teman atau relasi berada 
di urutan ke-2, ada 10 orang memiliki nilai 6,7\%. Responden yang mengetahui Berrybenka dari keluarga berada di urutan ke-3, ada 9 orang memiliki nilai 6\%. Responden yang mengetahui Berrybenka dari brosur berada di urutan ke-4, ada 4 orang memiliki nilai 2,6\%. Responden yang mengetahui Berrybenka dari lainnya (televisi) ada di urutan ke-5, ada 3 orang memiliki nilai $2 \%$.

Tabel 5. Karakteristik berdasarkan Mengetahui Berrybenka

\begin{tabular}{lr}
\hline Mengetahui E-Commerce Berrybenka & Jumlah \\
\hline Teman/Relasi & 10 \\
Keluarga & 9 \\
Social Media & 124 \\
Brosur & 4 \\
Lainnya (Televisi) & 3 \\
\hline TOTAL & 150 \\
\hline
\end{tabular}

Sumber: Data diolah, 2020

Untuk tahu berkaitan atau tidaknya antara variabel independen dan variabel dependen satu sama lain, dilakukan beberapa uji diantaranya menggunakan uji koefisien determinasi, uji F tabel, sera uji T tabel. Setelah melakukan uji koefisien determinasi, didapatkan hasil seperti pada Tabel 6.

Tabel 6. Hasil Uji Koefisien Determinasi

\begin{tabular}{rlrrr}
\hline Model & R & \multicolumn{1}{c}{ R Square } & Adjusted R Square & Std. Error of the Estimate \\
\hline 1 & .870 & .726 & .745 & 1.385 \\
\hline
\end{tabular}

Sumber: Data diolah, 2020

Hasil berdasarkan Tabel 6, didapat angka Adjusted R square yaitu 74,5\%. Karena itu, hasil tersebut memperlihatkan kemampuan variabel bebas menafsirkan variabel terikat mencapai $74,5 \%$. Sementara itu sisanya, $25,5 \%$ dapat disebabkan pengaruh variabel lainnya yang tidak termasuk diteliti pada penelitian ini.

Tabel 7. Hasil Uji F Tabel

\begin{tabular}{lrrrrr}
\hline \multicolumn{1}{c}{ Model } & Sum of Squares & \multicolumn{1}{c}{ df } & Mean square & F & Sig. \\
\hline Regression & 91.275 & 3 & 30.419 & 5.546 & .001 \\
Residual & 800.743 & 146 & 5.485 & & \\
Total & 892.000 & 149 & & & \\
\hline
\end{tabular}

Sumber: Data diolah, 2020

Untuk tahu signifikan atau tidaknya yang berpengaruh antara variabel independen (X) dengan variabel dependen (Y) akan memakai uji F, dan untuk tahu suatu hubungan dari variabel bebas terhadap variabel terikat akan menggunakan software SPSS versi 23. Berdasarkan hasil uji F yang ditunjukkan Tabel 7, dilihat bernilai signifikan menunjukkan 0,001. Karena 0,001 < 
0,05, disimpulkan $\mathrm{H}_{1}$ diterima. Hal ini memiliki arti kualitas sistem, kualitas informasi, dan kualitas layanan memiliki kaitan signifikan secara simultan untuk variabel kepuasan konsumen.

Berdasarkan hasil pengujian $\mathrm{T}$ tabel, setelah dilakukan pengujian, mendapatkan hasil yang ditunjukkan pada Tabel 8.

Tabel 8. Hasil Uji T Tabel

\begin{tabular}{lrrrrr}
\hline \multicolumn{1}{c}{ Model } & \multicolumn{1}{c}{ B } & Std. error & Beta & \multicolumn{1}{c}{ T } & \multicolumn{1}{c}{ Sig. } \\
\hline (constant) & 1.653 & 2.049 & & 5.403 & .000 \\
Kualitas Sistem & .032 & .048 & .445 & 1.367 & .238 \\
Kualitas Informasi & .347 & .068 & .167 & 2.793 & .000 \\
Kualitas Layanan & .187 & .059 & .276 & 3.146 & .002 \\
\hline
\end{tabular}

Sumber: Data diolah, 2020

Setelah melakukan uji nilai $\mathrm{t}$ untuk kualitas sistem didapatkan nilai $\mathrm{t}=1,367$ dan bernilai signifikan 0,238 . Oleh karena itu, $\mathrm{t}$ hitung $(1,367)<\mathrm{t}$ tabel $(1,655)$ serta bernilai signifikan $0,238>0,005, \mathrm{H}_{01}$ diterima, sehingga kualitas sistem tidak berkaitan secara signifikan terhadap kepuasan konsumen.

Setelah melakukan uji nilai $\mathrm{t}$ untuk kualitas informasi didapatkan nilai $\mathrm{t}=2,793$ dan bernilai signifikan 0,000. Oleh karena itu, $t$ hitung $(2,793)>t$ tabel $(1,655)$ serta bernilai signifikan $0,000<0,005$, maka, $\mathrm{H}_{2}$ diterima, sehingga kualitas informasi memiliki kaitan secara signifikan terhadap kepuasan konsumen.

Setelah melakukan uji nilai $\mathrm{t}$ untuk kualitas layanan didapatkan nilai $\mathrm{t}=3,146$ dan signifikansi 0,002. Jadi, $\mathrm{T}$ hitung $(3,146)>\mathrm{t}$ tabel $(1,655)$ serta signifikansi $0,000<0,005$, maka, $\mathrm{H}_{3}$ diterima, sehingga kualitas layanan memiliki kaitan secara signifikan terhadap kepuasan konsumen.

Setelah dilakukan uji koefisien determinasi di atas, dapat diperoleh bahwa $\mathrm{F}$ hitung $=$ 5,546 sehingga dapat disimpulkan bahwa $\mathrm{H}_{1}$ diterima karena $\mathrm{F}$ hitung $(5,546)>\mathrm{F}$ tabel $(2,67)$ signifikansi $0,001<0,005$. Hal tersebut menunjukkan bahwa kualitas sistem, kualitas informasi, dan kualitas layanan memiliki pengaruh simultan secara signifikan terhadap kepuasan konsumen. Hasil pengujian ini sejalan dengan hasil penelitian Widodo (2016) di mana nilai Adjusted $R$ Square berpengaruh sangat kuat disebabkan berada di atas angka 40\%. Tinggi serta rendahnya tingkat kepuasan pengguna sistem aplikasi dikarenakan ketidakstabilan kualitas sistem aplikasi, kualitas informasi serta kualitas layanan.

Sementara itu, berdasarkan hasil penelitian Suhendro (2015), menyebutkan kepuasan konsumen bukan hanya dipengaruhi dengan faktor dasar yang diwakilkan dengan variabel kualitas sistem, kualitas informasi, serta kualitas layanan saja. Akan tetapi, kepuasan konsumen juga disebabkan pengaruh variabel lainnya yang tidak termasuk diteliti pada penelitian ini. 


\section{Pengaruh Kualitas Sistem Terhadap Kepuasan Konsumen}

Mengacu pada hasil uji t (secara parsial) kualitas sistem tidak berpengaruh positif terhadap kepuasan konsumen pengguna aplikasi Berrybenka dengan signifikansi 0,238 > 0,05. Setelah dilakukan pengujian analisis regresi linier berganda kualitas informasi bernilai 0,032 peningkatan yang terjadi, kualitas sistem akan berakibat kepuasan konsumen (Y) menjadi mengalami kenaikan sebesar 0,238. Oleh karena itu, kesimpulannya bahwa $\mathrm{H}_{01}$ diterima serta $\mathrm{H}_{1}$ ditolak. Dikarenakan hal tersebut, kualitas sistem tidak berpengaruh signifikan secara parsial terhadap kepuasan konsumen. Berdasarkan hasil ini, penelitian yang dilakukan oleh Rudini (2016), juga menyebutkan hal yang sama. Menurutnya, kualitas sistem tidak memiliki pengaruh terhadap kepuasan konsumen karena konsumen sebagai pengguna sistem lebih berfokus kepada pelayanan dan kelengkapan pada aplikasi tersebut. Namun, berbeda dengan hasil penelitian oleh Widodo et al. (2016) mengatakan bahwa kualitas sistem memiliki peran yang besar dalam kemajuan perkembangan kualitas aplikasi yang baik sehingga konsumen sebagai pengguna dapat merasa puas.

\section{Pengaruh Kualitas Informasi Terhadap Kepuasan Konsumen}

Menurut hasil uji t (parsial) kualitas informasi ada pengaruh yang positif dengan kepuasan konsumen aplikasi Berrybenka, memiliki nilai $0,000<0,005$. Mengacu pada analisis regresi linier berganda, kualitas informasi bernilai positif sebesar 0,347 yang artinya akan terjadi peningkatan kualitas informasi yang berdampak pada kepuasan konsumen (Y) naik sebesar 0,347. Oleh karena itu, jika kualitas informasi $\left(\mathrm{X}_{2}\right)$ berkualitas baik, maka berdampak pada kepuasan konsumen (Y) pengguna aplikasi yang akan bertambah meningkat. Berdasarkan hal itu, maka $\mathrm{H}_{2}$ diterima, disimpulkan bahwa kualitas informasi memiliki kaitan parsial yang signifikan terhadap kepuasan konsumen. Alasan yang membuat kualitas informasi dinilai baik adalah kualitas informasi dari aplikasi Berrybenka memberikan kelengkapan informasi yang tersedia di aplikasi serta di website mengenai kelengkapan produk informasi produk yang mendetail sehingga konsumen merasa mudah mencari produk yang diinginkan.

Penelitian yang dilakukan oleh Guimaraes et al. (1992) menyebutkan hal yang sama, menurutnya rasa puas yang diperoleh konsumen dalam menggunakan sebuah sistem informasi mencerminkan kualitas sistem yang baik dan dapat diandalkan. Kepuasan konsumen dalam menggunakan sistem ialah bagaimana si pemakai tidak memandang kualitas sistem secara teknik melainkan melakukan pandangan secara nyata. Hasil riset yang sama juga disebutkan oleh Istianingsih \& Utami (2008), terbukti secara empirik jika kualitas sistem memiliki nilai positif terhadap kepuasan konsumen. Semakin baik kualitas informasi yang diberikan, maka akan memiliki pengaruh besar untuk tingginya kepuasan konsumen pengguna sistem tersebut. 


\section{Pengaruh Kualitas Layanan Terhadap Kepuasan Konsumen}

Menurut hasil uji t (parsial), kualitas layanan berpengaruh positif pada kepuasan konsumen memiliki nilai 0,002 < 0,05. Menurut uji regresi linier berganda, kualitas layanan bernilai positif 0,187 untuk peningkatan kualitas layanan akan berdampak pada kepuasan konsumen (Y) mengalami kenaikan sampai 0,187. Jadi, jika kualitas layanan $\left(\mathrm{X}_{3}\right)$ memiliki kualitas yang baik, akan menyebabkan tingginya tingkat kepuasan konsumen (Y) dari konsumen aplikasi Berrybenka. Alasannya karena layanan dari aplikasi Berrybenka membantu konsumen yang kebingungan untuk memesan produk karena customer service Berrybenka selalu menjawab pertanyaan konsumen dengan informatif.

Hasil dari temuan ini sesuai dengan riset yang dilakukan Wang (2007) yang menguji seberapa suksesnya $e$-commerce di Taiwan, serta Wang \& Liao, (2007) menguji suksesnya $e$ government Taiwan. Dari hasil tersebut ditemukan adanya kaitan positif antara kualitas layanan dengan pemakaian sistem. Hal tersebut terjadi dikarenakan lingkungan sistem dijadikan sebagai pendukung dari layanan yang digunakan.

Menurut pendapat dari Parasuraman (1985), hal tersebut juga dibenarkan karena menurutnya kualitas layanan adalah dibandingkan antara kualitas layanan yang dikatakan oleh konsumen bersama kualitas yang sebaiknya sudah dilakukan oleh departemen informasi. Ia melanjutkan, kualitas pelayanan tergantung dari ketidaksamaan antara layanan yang menjadi ekspektasi dengan kenyataan. Pelayanan tersebut tidak memuaskan jika ekspektasinya tinggi. Sedangkan, pelayanan akan dikatakan memiliki kualitas jika ekspektasinya lebih rendah.

\section{E. KESIMPULAN}

Hasil dari pengujian koefisien determinasi didapat nilai R-Square adalah 74,5\%. Sementara itu sisanya, 25,5\% dapat disebabkan pengaruh variabel yang tidak meliputi untuk diteliti pada penelitian ini. Kualitas informasi dan kualitas layanan terbukti secara parsial memiliki kaitan parsial terhadap kepuasan konsumen memiliki nilai signifikan $<0,005$. Sedangkan kualitas sistem tidak berkaitan parsial atas kepuasan konsumen. Kualitas informasi memiliki nilai signifikan 0,000, kualitas informasi signifikansi bernilai 0,002, serta kualitas sistem signifikansi bernilai 0,238. Kualitas sistem, kualitas informasi, dan kualitas layanan terbukti memiliki pengaruh secara simultan terhadap kepuasan konsumen diperoleh nilai $\mathrm{f}$ hitung 5,546 dengan nilai signifikansi 0,001 . Karena nilai f hitung $(5,546)>(2,67)$, serta signifikansi $(0,001)<0,005$ 


\section{Saran untuk Perusahaan}

Penerapan kualitas sistem pada aplikasi Berrybenka belum sepenuhnya memadai. Hal ini dikarenakan response time pada aplikasi Berrybenka masih tergolong lambat. Pada komponen ini, penulis menyarankan adanya pemeliharaan aplikasi (maintenance), bisa dilakukan secara sering dan bekala agar performa aplikasi tetap terjaga. Jika sebelumnya aplikasi Berrybenka kurang meng-update stok barang di aplikasi, maka sebaiknya Berrybenka melakukan pengecekan barang agar stok barang di aplikasi dan stok barang di website sinkron.

\section{Saran untuk Penelitian Selanjutnya}

Penelitian ini memiliki keterbatasan untuk variabel kualitas sistem, kualitas informasi, dan kualitas layanan terhadap kepuasan konsumen saja. Oleh karenanya, saran yang bisa disampaikan kepada penelitian di masa depan adalah masih terdapat banyak faktor lain selain variabel kepuasan pelanggan yang bisa berpengaruh pada variabel kualitas sistem, kualitas informasi serta kualitas layanan seperti dapat menggunakan variabel loyalitas pelanggan, atau juga minat pembelian ulang sebagai variabel terikatnya. Selain itu untuk penelitian selanjutnya dapat memakai metode dan teknik penelitian yang lebih tepat agar hasil yang diperoleh relevan dan dapat bermanfaat baik secara teoritis maupun praktis.

\section{DAFTAR PUSTAKA}

Brata, M. W., Hapsari, D. W., \& Yudowati, S. P. (2018). Pengaruh Kualitas Sistem, Kualitas Informasi, dan Kualitas Layanan terhadap Kepuasan Pengguna Sistem Informasi Keuangan (Studi Kasus Pegawai Keuangan Universitas Telkom). Jurnal EProceeding of Management, 5(1), 860.

DeLone, W., \& McLean, E. (2003). The DeLone McLean Model of Information System Success: A Ten-Year Update. Journal of Management Information System, 19(4), 930.

Guimares, T., Igbaria, M, and M. Lu. (1992). The determinants of DDS success: An integrated model. Decision Sciences, 23(2), 409-430.

Hornby, A. S. (2015). Oxford Advanced Learner's Dictionary of Current English. Oxford: Oxford University Press.

Istianingsih \& Utami, W. (2008). Pengaruh Kepuasan Pengguna Sistem Informasi Terhadap Kinerja Individu pada Pengguna Sistem Informasi Akuntansi di Indonesia, SNA XII, Palembang

Jogiyanto. (2009). Sistem Teknologi Informasi. Yogyakarta: Penerbit Andi.

Pratomo, Y. (2019, Mei 16). APJII: Jumlah Pengguna Internet di Indonesia Tembus 171 Juta Jiwa. Kompas. Diakses 3 Maret 2020, dari https://tekno.kompas.com/read/2019/05/16/03260037/apjii-jumlah-pengguna-internetdi-indonesia-tembus-171-juta-jiwa 
Kotler, P., \& Keller, K.L. (2009). Manajemen Pemasaran. Jakarta: Erlangga.

Kotler, P. \& Amstrong, G. (2009). Prinsip Prinsip Pemasaran. Jakarta: Erlangga.

Lupioadi, \& Hamdani. (2006). Manajemen Pemasaran Jasa. Jakarta: Salemba Empat.

Marlissa, D. (2015). Pengaruh Kualitas Sistem, Kualitas Informasi dan Kualitas Layanan Aplikasi Sistem Informasi Direktorat Jenderal Pajak (SIDJP) Terhadap Kepuasan Pengguna (Studi Kasus Pada Kantor Pelayanan Pajak Pratama Bandung Cibeunying). [Skripsi]. Bandung: Telkom University, Diakses 5 Maret 2020, dari https://openlibrary.telkomuniversity.ac.id/pustaka/104620/pengaruh-kualitas-sistemkualitas-informasi-dan-kualitas-layanan-aplikasi-sistem-informasi-direktorat-jenderalpajak-sidjp-terhadap-kepuasan-pengguna-studi-kasus-pada-kantor-pelayanan-pajakpratama-bandung-cibeunying-.html

Parasuraman, A., (2000). Technology Readiness Index (TRI): A multiple Item Scale to Measure Readiness to Embrace New Technologies, Journal of Service Research, 2(4), 307-320.

Pawirosumarto, S. (2016). Pengaruh Kualitas Sistem, Kualitas Informasi, dan Kualitas Layanan terhadap Kepuasan Pengguna Sistem E-Learning. Jurnal Ilmiah Manajemen, VI(3), 416-433

Priyantara, M. P. (2016). Pengaruh Kualitas Sistem, Kualitas Informasi, dan Kualitas Layanan Terhadap Kepuasan Konsumen (Studi Pada Konsumen Lazada di Indonesia). [Skripsi]. Bandung: Telkom University, Diakses 5 Maret 2020, dari https://openlibrary.telkomuniversity.ac.id/home/catalog/id/117582/slug/pengaruhkualitas-sistem-kualitas-informasi-dan-kualitas-layanan-terhadap-kepuasankonsumen-studi-pada-konsumen-lazada-di-indonesia-.html

Puspa, V. (2017). Pengaruh Kualitas Sistem, Kualitas Informasi, dan Kualitas Layanan HER Registrasi Igracias Terhadap Kepuasan Pengguna (Studi Kasus Terhadap Mahasiswa Telkom University). [Skripsi]. Bandung: Telkom University, Diakses 5 Maret 2020, dari https://openlibrary.telkomuniversity.ac.id/pustaka/127564/pengaruhkualitas-sistem-kualitas-informasi-dan-kualitas-layanan-her-registrasi-igraciasterhadap-kepuasan-pengguna-studi-kasus-terhadap-mahasiswa-telkom-university.html

Rudini, A. (2015). Pengaruh Kualitas Sistem, Kualitas Informasi, dan Kualitas Layanan SIA terhadap Kepuasan Mahasiswa. Jurnal Terapan Manajemen dan Bisnis 1(1), 39-49.

Saraswati, A. (2016). Pengaruh Kualitas Sistem, Kualitas Informasi, dan Kualitas Layanan Terhadap Kepuasan Pelanggan Pada Situs Commerce BLIBLI.COM). [Skripsi]. Bandung: Telkom University, Diakses 5 Maret 2020, dari https://openlibrary.telkomuniversity.ac.id/home/catalog/id/116969/slug/pengaruhkualitas-sistem-kualitas-informasi-dan-kualitas-layanan-terhadap-loyalitas-pelangganmelalui-kepuasan-pelanggan-pada-situs-commerce-blibli-com.html

Seddon, P. (1997). A Respecification and Extension of the Delone and Mclean's Model of is Success. Information System Research., Vol. 8, Hal. 240-250.

Sirclo. (2020, 22 Juli). 6 Kategori Produk yang Laris Dijual di Marketplace, Apa Saja? (online). Sirclo, Diakses 15 February 2021, dari https://www.sirclo.com/6-kategoriproduk-yang-laris-dijual-di-marketplace-apa-saja/ 
Suhendro, D. (2016). Pengaruh Kualitas Sistem, Kualitas Informasi, Kualitas Layanan dan Ekspektasi Kinerja terhadap Kepuasan Pengguna dalam Menerapkan Sistem Teknologi Informasi pada Koperasi di Kota Pematangsiantar. Jurnal Riset Sistem Informasi \& Teknik Informatika, 1 (1), 33-40.

Tjiptono, F., \& Chandra, G. (2011). Service, Quality \& Satisfaction (Tiga ed.). Yogyakarta: Penerbit Andi.

Warta Ekonomi. (2019, February 19). Pertumbuhan E-Commerce Pesat di Indonesia. Tersedia. Wartaekonomi. Diakses 3 Maret 2020, dari https://www.wartaekonomi.co.id/read216302/pertumbuhan-e-commerce-pesat-diindonesia

Wang, Y.S., \& Liao, Y.W. (2007). Assessing e-Government Systems Success: A Validation of the DeLone and McLean Model of Information Systems Success. Government Information Quaterly, 25(4) 717-733.

Wang, Y. (2007). Assessing e-commerce Systems Success: A Respecification and Validation of the DeLone and McLean model of IS success, Blackwell Publishing Ltd, Information Systems Journal, 18(5), 529-557.

Widodo, A., Putranti, H. D., \& Nurcahyati. (2016). Pengaruh Kualitas Sistem Aplikasi dan Kualitas Informasi terhadap Kepuasan Pengguna Sistem Aplikasi RTS (Rail Ticketing System) denagn Kepercayaan sebagai Variabel Mediasi. Media Ekonomi dan Manajemen, 31(2), 160-181. 